\title{
Svitlana Vnuchko
}

PhD in Political science, Associate Professor, Politology Department, Taras Shevchenko National

University of Kyiv (Kiev, Ukraine)

https://orcid.org/0000-0001-9176-1304

e-mail: vnuchko@ukr.net

\section{INTERACTION OF POWER AND SOCIETY WITHIN THE FRAMEWORK OF THE ASSOCIATION AGREEMENT BETWEEN UKRAINE AND THE EU AND EASTERN PARTNERSHIP POLICY PAPERS}

\begin{abstract}
Communication of public authorities and society, in particular, public authorities and separate social groups, is an important component of the political and managerial practice of modern society.

The world practice shows that effective communication between these actors provides citizens with free access to information, improves the efficiency of government and local self-government bodies, and creates a favourable environment for business development, which in turn serves as the basis for economic stability and the engine of the country's social and economic development.

In the conditions of the development of the information society, new models, mechanisms, platforms of relations and communication between the authorities and the public are emerging. The constructive interaction between power structures and civil society organizations, with a «feedback» component, will contribute to meeting the needs and interests of citizens and strengthening the credibility of both power structures and civil society institutions. Moreover, it will improve the status of Ukraine at the international level by ensuring compliance with the Association Agreement and creating the preconditions for Ukraine to achieve the 20 key priorities of the Eastern Partnership 2020. In the future, consideration should be given to this issue in order to deepen, broaden and improve the effectiveness of the communication component of the government bodies and civil society organizations in Ukraine.

In the implementation of communication interaction, special attention should be paid to providing a feedback between communicators. After all, it is this component of the communications process that provides interaction and information about the society's reaction to the results of the implemented decisions.

Purpose of the research: to conduct a scientific, theoretical and practical analysis of functioning of the existing in Ukraine communication platforms of civil society organizations and authorities in the framework of the Association Agreement and the Eastern Partnership policy papers.
\end{abstract}

Key words: communication; interaction of government and society; business associations; civil society organizations; Eastern Partnership 
УДК 35.01:328.18

DOI: $10.17721 / 2415-881 x .2019 .83 .79-85$

\title{
Внучко Світлана Миколаївна
}

Кандидат політичних наук, доцент кафедри політології, Київський національний університет імені Тараса Шевченка ( м. Київ, Україна)

https://orcid.org/0000-0001-9176-1304

e-mail: vnuchko@ukr.net

\section{ВЗАЄМОДІЯ ВЛАДИ ТА СУСПІЛЬСТВА В РАМКАХ УГОДИ ПРО АСОЦІАЦІЮ МІЖ УКРАЇНОЮ ТАЄС ТА ПРОГРАМНИХ ДОКУМЕНТІВ СХІДНОГО ПАРТНЕРСТВА}

\begin{abstract}
Резюме
Взаємодія влади та суспільства, зокрема, органів державної влади та окремих соціальних груп, виступає важливою складовою політичної та управлінської практики сучасного суспільства.

Світова практика підтверджує, що ефективна комунікація між органами державної влади та організаціями громадянського суспільства забезпечує громадянам вільний доступ до інформації, підвищує ефективність органів влади, органів місцевого самоврядування та створює сприятливе середовище для розвитку бізнесу, що, в свою чергу, є основою для економічної стабільності та двигуном соціального та економічного розвитку країни.

В умовах розвитку інформаційного суспільства України виникають нові моделі, механізми, платформи відносин та комунікації між владою та громадськістю. Конструктивна взаємодія між владними структурами та організаціями громадянського суспільства України зі складовою «зворотного зв'язку» сприятиме задоволенню потреб та інтересів громадян та зміцненню авторитету як владних структур, так і інститутів громадянського суспільства, а також покращить статус України на міжнародному рівні шляхом забезпечення дотримання положень Угоди про асоціацію та створення передумов для досягнення Україною 20 основних пріоритетів Східного партнерства 2020. Саме тому з метою поглиблення, розширення та підвищення ефективності комунікаційної складової органів державної влади та організацій громадянського суспільства в Україні дане питання потребує додаткової уваги.

При здійсненні комунікаційної взаємодії особливу увагу слід приділяти наданню зворотного зв'язку між комунікаторами. Зрештою, саме ця складова комунікаційного процесу забезпечує взаємодію та надання інформації про реакцію суспільства на прийняті рішення.

Мета дослідження: провести науковий, теоретичний та практичний аналіз функціонування існуючих в Україні комунікаційних платформ органів державної влади та організацій громадянського суспільства в рамках Угоди про асоціацію та програмних документів Східного партнерства.
\end{abstract}

Ключові слова: комунікація; взаємодія влади і суспільства; бізнес-асоціації; організації громадянського суспільства; Східне Партнерство 


\section{Introduction}

Communication of public authorities and society, in particular, public authorities and separate social groups, is an important component of the political and managerial practice of modern society.

In the era of the information society, ensuring a meaningful dialogue between the government and non-government organizations (the so-called «third sector»), government and business (the socalled «second sector») is a prerequisite for the implementation of public policy and the key to the effectiveness of the decisions taken, rise in the level of trust and interaction of the main political actors in the relevant sphere.

The world practice shows that effective communication between these actors provides citizens with free access to information, improves the efficiency of government and local self-government bodies, and creates a favourable environment for business development, which in turn serves as the basis for economic stability and the engine of the country's social and economic development.

In the implementation of communication interaction, special attention should be paid to providing a feedback between communicators. After all, it is this component of the communications process that provides interaction and information about the society's reaction to the results of the implemented decisions.

The specific nature of communication between the authorities and society has long been the focus of attention of scholars, although there still remain a large number of issues to be addressed: the peculiarities of electronic communications, instruments, communication technologies, legal regulation of communication interaction, and so on. Recently, there is a lively discussion in the scientific community about the definition of key terms of communication science, such as Government Relations (GR), Lobbying, Public Affairs, and Advocacy [1, p. 82].

Analysis of recent research and publications. The peculiarities of the communication of public authorities are covered in the papers of T. Gromova, A. Yermolenko, M. Lashhkina, G. Pocheptsov, and O. Cheban. R. Rice and J. Henry are engaged in the study of the assessment of communication of public authorities. The communication aspects of the mass media, the issues of information security and the status of mass media are consistently studied by domestic experts V. Bebik, V. Ivanov, N. Hrytsiak, V. Kololko, N. Kostenko, O. Lytvynenko, M. Logunova, O. Nekrasova, G..Pocheptsov, I. Slisarenko, S.Chukut et al. Recently, most studies have focused on the problems of the development of public communications and modern mass media: V. Bortnikov, L. Degtyareva, A. Kudryachenko, M. Vlasenko, S. Zorko, and M. Syrotych.

Identification of unsettled parts of the problem. Most scientific studies deal with certain aspects, concepts, mechanisms of mass and political communication, and evaluation of communication functions of public authorities. This article analyzes the existing civil society platforms, the main task of which is to ensure communication within the framework of implementation of the provisions of the EU-Ukraine Association Agreement and «Eastern Partnership: 20 Key Deliverables for 2020».

The purpose of the article. To conduct a scientific, theoretical and practical analysis of functioning of the existing in Ukraine communication platforms of civil society organizations and authorities in the framework of the Association Agreement and the Eastern Partnership policy papers.

Achievement of the set goal has necessitated the following tasks: - analyze the provisions of regulations, strategies, programs that envision the platforms to provide a constructive dialogue of the government and civil society.-identify the forms, conditions and performance of such interaction within the existing platforms.

\section{Research methods}

When writing this Article, a complex of philosophical, philosophical, general scientific and special political methods was used. Methods of analysis and synthesis were used in the analysis of regulations, strategies, programs that envisage the creation of platforms for a meaningful dialogue of government and civil society organizations, as well as in the study of platform performance. The system method was used in studying the peculiarities of interaction and ensuring the implementation 
of the main components of effective communication between government bodies and civil society organizations.

\section{Results and discussion}

Ukraine has turned to European integration. The main documents governing the reform of the legislation and methods of public administration in Ukraine today are the EU-Ukraine Association Agreement and the 20 key priorities of the Eastern Partnership «Eastern Partnership: Focusing on Key Priorities and Deliverables».

European integration of Ukraine strengthens the dialogue of society and government authorities. The organizational and legal capacity of civil society institutions to articulate social interests, advocate and protect them is the platform for such a dialogue in Europe. It is understood that the success of the dialogue in certain countries depends directly on the joint efforts of public authorities and associations of citizens and their willingness to cooperate. Public associations have a real impact on public policy and bring pluralistic and democratic ideas, embodying the whole spectrum of ideas generated in civil society. Today, this process goes beyond national states, and international organizations are actively involved in it, which not only contributes to the strengthening of social dialogue, but also allows for the development of stable relations between states on the basis of common values of human rights protection, the rule of law and democracy [2, p. 196].

Communication as interaction, which characterizes a simple exchange of information neither in the past, nor today, nor the future can be the basis of dialogue between the state and society. Effective communication includes: training; direct communication; analysis of results; fulfilment of agreements. The last two components provide the effectiveness of communication interaction.

O. Cheban, a Ukrainian researcher, analyzing the methodological approaches to assessing communication campaigns in public administration, distinguishes external and internal components of the assessment, which are divided into four main types [3, p. 63].

Types of assessment of communication campaigns

№ Type of assessment Definition/purpose Examples of questions

1 Forming Assessment of strengths and weaknesses of materials and strategies before or during the campaign What does the target audience think about the problem? What messages work and with which audiences? Who are the best communicators?

2 Assessment of the process Measurement of efforts and direct outputs of the campaign - what has been done and how much has been done. Analyses of the campaign implementation and how the planned activities work How many materials were involved? What was the campaign holding period? How many people were covered?

3 Assessment of the result Measurement of the impact and changes that result from the campaign. Assessment of results for the target group or community that benefits from the strategies and activities. Measurement of changes in the policy. Have there been any effective changes (beliefs, views, social norms)? Were there any changes in behaviour? Have there been any changes in policy?

4 Impact assessment Measurement of community-level changes or long-term results that are achieved as a consequence of combined effects of the campaign on the behaviour of individuals and persistence of such behaviour. Attempts to determine whether these effects were caused by the campaign. Does the behaviour correspond to the expected results? Do system changes take place?

The need for effective communication is defined by the provisions of the EU-Ukraine Association Agreement. So, according to Articles 469-470 of the Agreement, the Ukraine-EU Civil Society Platform (CSP) is set up - a body composed of representatives of the civil society of Ukraine on the one hand and members of the European Economic and Social Committee (EESC) on the other hand [4]. The platform is one of the four bodies of the Association, along with the Association Council, Association Committee and Parliamentary Committee of the Association. And if the former are represented by the government and the parliament, the CSP is set up to ensure the proper role of the public in the implementation of the Association Agreement [5]. 
The CSP may provide recommendations to the Association Council. The Association Committee and the Parliamentary Committee of the Association shall maintain regular contacts with representatives of the Civil Society Platform in order to obtain their views on the achievement of the objectives of the Agreement, thus facilitating communication between the authorities and society.

Members of the CSP include representatives of trade unions, employers' organizations and nongovernmental organizations. Representatives of CSP communicate with the authorities in Ukraine and the international community on an ongoing basis.

The provisions of the Association Agreement provide for the creation of another platform for the negotiations of civil society organizations with the authorities. Thus, Article 299 of Chapter 13 of the Agreement provides for the establishment of an Advisory Group on Sustainable Development in order to provide recommendations on the implementation of this Chapter. The Advisory Group shall consist of independent representative non-governmental organizations, which objectively represent employers' 'and workers' organizations, non-governmental organizations and other parties concerned. The members of the Advisory Group shall meet at an open Civil Society Forum to support a dialogue covering aspects of sustainable development of trade relations between the parties [6].

Assessing trade's impact of on sustainable development of the labor market constitutes an important element while implementing the Chapter 13 of the Association Agreement. The effectiveness of negotiations with the authorities at this stage should be achieved by ensuring inclusiveness of a wide range of civil society organizations, trade unions and employers' organizations. However, best international practices should be a solid base for trade promotion, leading to full and effective employment and decent work for everyone, as well as ensuring Ukraine's compliance with international labour standards.

Establishment of the Domestic Advisory Group on sustainable development, which monitors the implementation of Chapter 13 of the Association Agreement and prepares relevant recommendations, would ensure the realization of fundamental principles and labor rights in Ukraine, as defined by ILO Conventions ratified by Ukraine, as wells as facilitate the pursue of decent work, full and effective employment in Ukraine while developing international trade. DAG should be composed of employers' organizations, trade unions and CSO's representatives.

The Ukrainian National Platform of the Eastern Partnership Civil Society Forum (UNP EaP CSF) was established on January 29, 2011 and operates within the framework of the Eastern Partnership Civil Society Forum (hereinafter referred to as the EaP CSF), a multinational platform of civil society organizations from the Eastern Partnership countries, EU Member States, both international and national networks. The platform aims to provide a regular dialogue between representatives of civil society organizations, Ukrainian officials and parliamentarians, as well as representatives of European institutions in the implementation and monitoring of the Eastern Partnership initiative of the EU on a bilateral and multilateral basis. The platform now includes 202 civil society organizations of Ukraine [7].

In December 2016, the European Commission and the European External Action Service issued a Joint Working Paper «Eastern Partnership — Focusing on Key Priorities and Deliverables» [8]. The document is intended to improve the essence of the Eastern Partnership policy and to more clearly define the obligations for the institutions involved in its implementation; it defines the list of priority areas, as well as the tasks that are planned to be implemented within the framework of the Eastern Partnership (EaP) until 2020. Following the discussion of the document, EU Member States and partner countries within the framework of the Eastern Partnership, the European Commission and the European External Action Service have revised «20 Expected Achievements by 2020». The main objective is to identify clear, tangible results for citizens provided within the framework of the Eastern Partnership in accordance with the four priority areas approved in Riga, on the basis of already existing commitments from both the EU and partner countries. «20 Expected Achievements by 2020» focuses on selected key activities within the Eastern Partnership and is a practical tool for a more consistent, 
effective and integrated implementation of the Eastern Partnership policy. The document is closely linked with the European Neighbourhood Policy, and also takes into account the relationship between the EU and the EaP countries, in particular, the commitments set forth in the agreements and association agendas, as well as the Partnership Priorities. It is also expected that a close relationship between the EU assistance and national reform plans will increase the effectiveness of support and motivate partner countries to implement reforms. The document also emphasizes the need for communication between the authorities and society at the level of the countries of the Eastern Partnership and at the European level. This, in turn, will provide a better, more precise and individualized strategic communication activity that will lead to a better understanding and a higher degree of EU trust among the citizens of the Eastern European countries [8].

\section{Conclusions}

In the conditions of the development of the information society, new models, mechanisms, platforms of relations and communication between the authorities and the public are emerging. The constructive interaction between power structures and civil society organizations, with a «feedback» component, will contribute to meeting the needs and interests of citizens and strengthening the credibility of both power structures and civil society institutions. Moreover, it will improve the status of Ukraine at the international level by ensuring compliance with the Association Agreement and creating the preconditions for Ukraine to achieve the 20 key priorities of the Eastern Partnership 2020. In the future, consideration should be given to this issue in order to deepen, broaden and improve the effectiveness of the communication component of the government bodies and civil society organizations in Ukraine.

\section{СПИСОК ЛІТЕРАТУРИ:}

1. Клімович С. О. Дослідження Government Relations як комунікації між владою та бізнесом: термінологічний аспект. Стратегічні пріоритети: Науково-аналітичний щоквартальний збірник. 01/2010. N1. С. 82-85.

2. Кучабський О., Бажинова О.Механізми комунікації влади та громадськості в умовах глобалізації [Електронний ресурс]. Публічне управління: теорія та практика. 2012. № 4 (12). C. 196-201. Режим доступу: http://www. kbuapa. kharkov. ua/e-book/putp/2012-4/doc/4/06.pd

3. Чебан О.Оцінювання виконання комунікаційної функції органів публічної влади [Електронний ресурс]. Public Administration and Local Government. 2016. №2 (29). С. 59-66. Режим доступу: http://www. dridu. dp. ua/vidavnictvo/2016/2016_02 (29)/10.pdf

4. Угода про асоціацію між Україною та Європейським союзом [Електронний pecypc]—Режим доступу: http://zakon3.rada. gov. ua/laws/show/984_011

5. Офіційний сайт Платформи громадянського суспільства Україна-ЄС [Електронний pecypc]. Режим доступу: http://eu-ua-csp. org. ua/

6. Угода про асоціацію між Україною та Європейським союзом [Електронний ресурс]. Режим доступу: http://zakon3.rada. gov. ua/laws/show/984_011

7. Офіційний сайт Української національної платформи Форуму громадянського суспільства Східного Партнерства [Електронний ресурс]. Режим доступу: http://eap-csf. org. ua/.

8. Офіційний сайт Європейської комісії. Спільний робочий документ «Східне Партнерство-концентруючись на ключових пріоритетах та очікуваних досягненнях» [Електронний ресурс]. 15.12.2016 - 42 с. Режим доступу: https://s3platform. jrc. ec. europa. eu/-/ eastern-partnership-focusing-on-key-priorities-and-deliverables?inheritRedirect=true 


\section{REFERENSES:}

1. Cheban O. (2016), «Evaluation of the performance of the communication function of public authorities», Public Administration and Local Government, [Online], vol. 2, no 29, available at: http:// www. dridu. dp. ua/vidavnictvo/2016/2016_02 (29)/10.pdf (Accessed 4 Sept 2018).

2. Klimovich S. (2010), «Investigating Government Relations as Communication between Government and Business: A Terminological Aspect», Stratehichni priorytety: Naukovo-analitychnyi shchokvartalnyi zbirnyk, vol. 1, pp. 82-85.

3. Kuchabsky O., Bazhinova O. (2012), «Mechanisms of communication between the authorities and the public in the context of globalization», Publichne upravlinnia: teoriia ta praktyka, [Online], vol. 4, no 12, available at: http://www. kbuapa. kharkov. ua/e-book/putp/2012-4/doc/4/06.pd (Accessed 4 Sept 2018).

4. The official site of the European Commission (2016), «Eastern Partnership — Focusing on Key Priorities and Deliverables», available at: https://s3platform. jrc. ec. europa. eu/-/eastern-partnershipfocusing-on-key-priorities-and-deliverables?inheritRedirect=true

5. The official site of the Ukraine-EU Civil Society Platform (2015), «About The Ukraine-EU Civil Society Platform», available at: http://eu-ua-csp. org. ua/ (Accessed 4 September 2018).

6. The official site of the Ukrainian National Platform of the Eastern Partnership Civil Society Forum (2011), «EaP Civil Society Forum», available at: http://eap-csf. org. ua/. (Accessed 4 September 2018).

7. The Verkhovna Rada of Ukraine (2014), «Association Agreement between the European Union and Ukraine», available at: https://zakon3.rada. gov. ua/laws/show/984_011 (Accessed 29 September 2018)

8. The official website of the European Commission. Joint Working Paper on the Eastern Partnership - Focusing on Key Priorities and Expected Achievements [Online resource]. 12/15/2016 42 p. available at: https://s3platform. jrc. ec. europa. eu/-/eastern-partnership-focusing-on-keypriorities-and-deliverables?inheritRedirect=true 